\title{
Ontology-Based loT Healthcare Systems (IHS) for Senior Citizens
}

\author{
Sakshi Gupta, Birla Institute of Technology, Mesra, India \\ (iD) https://orcid.org/0000-0001-7793-9858 \\ Umang Singh, Institute of Technology and Science, Ghaziabad, India
}

\begin{abstract}
Rapid incremental growth in population increases the virulence of infectious diseases worldwide. Due to this, health hazards with population growth raise pollution in the air, water, and soil and affect the immunity of individuals. To handle the situation, reliable and easy-to-reach healthcare services are required. The proliferation of connected technologies along with the internet of things (IoT) are providing modern healthcare with extensive care. All-pervading IoT technology is gaining attraction nowadays. This paper presents a brief about the e-healthcare system along with its framework. This attempt also presents the ontology approach as data produced by healthcare applications is vast and unstructured and needs to be organized into a proper format with a smooth flow of data to result in less request-response time. Further, this paper discusses the impact of disease on senior citizens in the current scenario.
\end{abstract}

\section{KEYWORDS}

Dataset, Diseases, Elderly People, Healthcare System, Infections, IoT, Ontology, OWL, Risk Factors, URI

\section{INTRODUCTION}

A reliable and prompt E-healthcare system is the immense requirement of today's scenario. The world is facing a pandemic COVID-19(Coronavirus Disease-19) (Recalcati, 2020) situation and exploring the possibilities to find out the related vaccine as soon as possible. As this disease has symptoms like fever, fatigue, cough, anosmia, ageusia, and human to human transfer, though no standard vaccine has evolved to date. Studies show that senior citizens are at high-risks of attacked by COVID-19 as their immune system is low. It is difficult for them to go to hospitals and labs for a routine health check-up or in an emergency. An E-healthcare system (electronic healthcare system) (Maglogiannis, 2009) requires that we can collect all the data of patients, doctors, nurses, and other actors directly related to healthcare. Data can be gathered from hospitals, labs, and sometimes from sensors attached to patient's bodies or nearby bodies. At the data acquisition layer, data should be acquired from a meaningful perspective so that it can be re-used without less filtration process. Analysis of that data is necessary to find out the existence of any disease. Various E-healthcare record systems are overviewed in (Yadav et al., 2018). The Internet of Things (IoT) has already endowed its application 
as a smart healthcare system or intelligent healthcare system sometimes termed as IoMT (Internet of Medical Things). IoMT is a collaboration of medical things and applications to provide connectivity to healthcare systems over the internet. IoT helps to access healthcare data quickly for large scale applications. This paper is organized as follows. Section II provides some related works. Section III presents IoT healthcare systems and Risk factors for elderly people. Section IV describes the framework of IoT healthcare system and related methodology. Section V presents research findings from the current scenario related to Covid19. The final section concludes our study.

\section{LITERATURE REVIEW}

Tun et. al (2020) discussed an overview about 11 different applications of IoT and wearables like aged care monitoring, chronic patient healthcare monitoring, the clinical applications, emergency conditions, mental health, and others to supervise healthcare of senior citizens and pointed out clinical point of view in comparison to technology point of view. Authors Lee et al., (2020) focused on older people and people with disabilities, caregivers, and healthcare providers with the help of a face-to-face questionnaire. The authors mentioned that discrepancies are still present in the current scenario related to the requirement of IoT healthcare services. As people require these technical services mostly in emergencies as well as persons with mild disabilities. In Pinto et al., (2017) a complete IoT healthcare system has been provided for monitoring the health life of elder persons and trigger alarm in case of any emergency. A wrist band is used by an elder person can collect data and send it to the We-care server with the help of a 6LoWPAN protocol. An Elderly IoT healthcare system is proposed in Park et al., (2017) where authors focus on brain stroke issues. Parameters like blood pressure, pulse rate, sugar level, oxygen level, motion tracking are tracked in senior citizens via wearable devices to control any emergency. Ray et. al (2014) proposed a five-layered framework named home health hub IoT (H3IoT) for elderly people who are in a homely environment. Basanta et. al(2016) presented solutions for monitoring the health of elder citizens with the integration of IoT technology. Authors have presented their health issues in older natives related to physical disability and severe psychological depressions.

Related work mentioned in [14-23] is that the organization of congregate data is one of the focal challenge as most data is available in a heterogeneous format. A semantic and flexible data model is required to give a smooth flow in data. For this, ontology is used to explain the properties of a domain by describing concepts and relationships among entities of the domain. Entities in IoT like IoT devices, IoT applications, users, developers are not able to use homogeneous platforms all the time, so ontologies provide a consistent and formal representation of data among these entities. Here, semantic web comes into the picture. According to the World Wide Web (W3C) - the "semantic web provides a common framework that allows data to be shared and reuse across applications enterprise and community" [24]. Semantic web technologies like- Resource description framework (RDF), Web Ontology Language (OWL) are used to link data over the web in such a way so that machines can understand and manipulate data. The semantic web in the IoT field sometimes referred as the semantic web of things (SWoT) is responsible for representing and describing the things on the web via Uniform Resource Identifier (URI) or Internationalized Resource Identifier (IRI) and relationship is defined among these things by RDF [25]. Ontology provides domain knowledge and standardization as well as codification of that knowledge in a machine-understandable format so it can be reused by people, databases, and applications [26]. According to the W3C consortium, the Semantic web can be used to integrate varied data in one seamless application, as it provides a common framework that allows the sharing and reusing of data on the web. Ontology opens new ways of data integration and analysis in the IoT healthcare system where diverse data can be expressed and amalgamated by using some ontology languages like ontology web language (OWL) and resource description framework (RDF).

In [27] author discussed a semantic middleware data model to integrate IoT healthcare information systems to electronic healthcare records (EHR) with the help of ontology. Two components, semantic 
Table 1. Comparison of technologies and methodologies identified as a solution for diseases in the existing scenario

\begin{tabular}{|c|c|c|c|c|c|c|}
\hline S.No & $\begin{array}{c}\text { Existing } \\
\text { Proposed Model }\end{array}$ & $\begin{array}{l}\text { Identified } \\
\text { diseases }\end{array}$ & Methodology Used & Process Flow & Data collection methods & $\begin{array}{l}\text { Factors still } \\
\text { unexplored }\end{array}$ \\
\hline 1. & $\begin{array}{l}\text { The IoT-based } \\
\text { heart disease } \\
\text { monitoring } \\
\text { system for } \\
\text { pervasive } \\
\text { healthcare } \\
\text { service. (2017) } \\
\text { (Li et al., 2017) }\end{array}$ & $\begin{array}{l}\text { Heart diseases } \\
\text { (blood pressure, } \\
\text { ECG, heart rate, } \\
\text { pulse rate, blood } \\
\text { glucose, } \mathrm{SpO} 2 \text {, } \\
\text { and blood fat) }\end{array}$ & $\begin{array}{l}\text { Based on data } \\
\text { acquisition and data } \\
\text { transmission. }\end{array}$ & $\begin{array}{l}\text { A Prototype can } \\
\text { monitor the patient's } \\
\text { physical parameters } \\
\text { and transmit them. The } \\
\text { Smartphone is used } \\
\text { as a connector and a } \\
\text { web-based application } \\
\text { is used for doctors to } \\
\text { monitor data. }\end{array}$ & $\begin{array}{l}\text { Parameters and frequency } \\
\text { of parameters are designed } \\
\text { after interviewing medical } \\
\text { experts. } \\
\text { Physical signals are } \\
\text { collected via various } \\
\text { sensors. } \\
\text { ECG-128Hz (Sampling } \\
\text { frequency) } \\
\text { BP-2seconds } \\
\text { SpO2-2sec }\end{array}$ & $\begin{array}{l}\text { Not considered } \\
\text { for the elderly age } \\
\text { group }\end{array}$ \\
\hline 2. & $\begin{array}{l}\text { Internet of } \\
\text { things-based } \\
\text { personal device } \\
\text { for diabetes } \\
\text { therapy } \\
\text { management in } \\
\text { ambient assisted } \\
\text { living (AAL). } \\
\text { (2011)(Jara et al., } \\
\text { 2011) }\end{array}$ & $\begin{array}{l}\text { Diabetes mellitus } \\
\text { in elderly people }\end{array}$ & $\begin{array}{l}\text { Based on therapy model } \\
\text { including technologies- } \\
\text { RFID, 6LoWPAN }\end{array}$ & $\begin{array}{l}\text { Self-monitoring } \\
\text { operation is referred } \\
\text { for blood glucose. } \\
\text { Information is received } \\
\text { through instructions } \\
\text { by doctors and nurses } \\
\text { at home. }\end{array}$ & $\begin{array}{l}\text { Diabetes Information } \\
\text { System from internet }\end{array}$ & $\begin{array}{l}\text { Not defined any } \\
\text { security }\end{array}$ \\
\hline 3. & $\begin{array}{l}\text { An E-health } \\
\text { system for } \\
\text { monitoring } \\
\text { elderly health } \\
\text { based on Internet } \\
\text { of Things and } \\
\text { Fog computing } \\
\text { (Hassen et al., } \\
\text { 2019) }\end{array}$ & $\begin{array}{l}\text { Physiological and } \\
\text { general parameters } \\
\text { like - ECG, Body } \\
\text { temperature, } \\
\text { BP, oxygen } \\
\text { level, pulses are } \\
\text { collected }\end{array}$ & $\begin{array}{l}\text { Proposed an } \\
\text { e-healthcare system for } \\
\text { elder people. } \\
\text { Based on IoT and Fog } \\
\text { computing. }\end{array}$ & $\begin{array}{l}\text { Data is analyzed as } \\
\text { well as stored and send } \\
\text { to the cloud via REST } \\
\text { API. The resulting } \\
\text { feedback is found } \\
\text { high after providing } \\
\text { awareness users. }\end{array}$ & $\begin{array}{l}\text { Used the HW V2 platform } \\
\text { and an android app for fog } \\
\text { computing. }\end{array}$ & $\begin{array}{l}\text { Not focused } \\
\text { on any specific } \\
\text { disease }\end{array}$ \\
\hline 4. & $\begin{array}{l}\text { Identifying risky } \\
\text { environments } \\
\text { for COPD } \\
\text { patients using } \\
\text { smartphones and } \\
\text { the internet of } \\
\text { things objects. } \\
\text { (2014) (Kouris } \\
\text { \& Koutsouris, } \\
\text { 2014) }\end{array}$ & $\begin{array}{l}\text { Chronic obtrusive } \\
\text { pulmonary disease } \\
(\mathrm{COPD})\end{array}$ & $\begin{array}{l}\text { Based on the data } \\
\text { processing scheme and } \\
\text { cloud-hosted services. }\end{array}$ & $\begin{array}{l}\text { Successfully identify } \\
\text { risky environments on } \\
\text { a small scale. } \\
\text { Sensors are deployed } \\
\text { around patients so that } \\
\text { data can be received } \\
\text { through a smartphone. }\end{array}$ & $\begin{array}{l}\text { MATLAB, WEKA, } \\
\text { wearable devices using } \\
\text { Arduino }\end{array}$ & $\begin{array}{l}\text { Not focused on } \\
\text { elderly }\end{array}$ \\
\hline 5. & $\begin{array}{l}\text { Smart Portable } \\
\text { Monitoring } \\
\text { Device for } \\
\text { Asthma Patients } \\
\text { (2016) (Abinayaa } \\
\text { \& Raja, 2016) }\end{array}$ & Asthma disease & $\begin{array}{l}\text { The proposed system is } \\
\text { used to track real-time } \\
\text { data of asthma patients } \\
\text { and instructions are } \\
\text { delivered by medical } \\
\text { staff accordingly. } \\
\text { Based on android } \\
\text { application software and } \\
\text { a Wi-Fi module. }\end{array}$ & $\begin{array}{l}\text { Real-time data of } \\
\text { asthma disease like- } \\
\text { body temperature, } \\
\text { Air pressure, Carbon } \\
\text { Dioxide are tracked } \\
\text { and get instructions by } \\
\text { doctors. }\end{array}$ & $\begin{array}{l}\text { Temperature sensor, } \\
\text { accelerometer, Rpi } 2 \text { card. } \\
\text { Real-time data collection } \\
\text { of patients. }\end{array}$ & $\begin{array}{l}\text { Not focused on } \\
\text { elderly }\end{array}$ \\
\hline 6. & $\begin{array}{l}\text { Remote health } \\
\text { monitoring } \\
\text { of the elderly } \\
\text { through wearable } \\
\text { sensors (2019) } \\
\text { (Al-Khafajiy et } \\
\text { al., 2019) }\end{array}$ & $\begin{array}{l}\text { Physiological and } \\
\text { general parameters } \\
\text { are collected for } \\
\text { senior citizen in } \\
\text { Ambient Assistive } \\
\text { Living (AAL) } \\
\text { environment } \\
\text { Parameters- } \\
\text { oxygen saturation, } \\
\text { pulses, BP }\end{array}$ & $\begin{array}{l}\text { Proposed an (SW- } \\
\text { SHMS) smart health } \\
\text { home-based monitor } \\
\text { system to gather } \\
\text { real-time data. Based } \\
\text { on smart phone, } \\
\text { technologies- ZigBee, } \\
\text { Bluetooth, and wearable } \\
\text { devices like- oximeter, } \\
\text { smart watch }\end{array}$ & $\begin{array}{l}\text { Faster response time, } \\
\text { fewer packet drops, } \\
\text { and low } \\
\text { Real-time data } \\
\text { gathered in patient's } \\
\text { layer, data send } \\
\text { to cloud layer and } \\
\text { Doctors will monitor } \\
\text { patients' data via } \\
\text { hospital layer }\end{array}$ & $\begin{array}{l}\text { Wearables, smartphone, } \\
\text { heartbeat sensor, Arduino } \\
\text { UNO device } \\
\text { Real time data collection } \\
\text { of patients via Wearables, } \\
\text { smartphone, heartbeat } \\
\text { sensor, Arduino UNO } \\
\text { device }\end{array}$ & $\begin{array}{l}\text { Not any specific } \\
\text { diseases }\end{array}$ \\
\hline 7. & $\begin{array}{l}\text { A diagnostic } \\
\text { prediction } \\
\text { model for } \\
\text { chronic kidney } \\
\text { disease in the } \\
\text { internet of things } \\
\text { platform (2020) } \\
\text { (Hosseinzadeh et } \\
\text { al., 2020) }\end{array}$ & $\begin{array}{l}\text { Chronic Kidney } \\
\text { Disease (CKD) }\end{array}$ & $\begin{array}{l}\text { Data is collected } \\
\text { using the IoT platform } \\
\text { and then data mining } \\
\text { algorithms is applied } \\
\text { to predict CKD. Based } \\
\text { on IoT platform and } \\
\text { data mining algorithms } \\
\text { SVM, Naïve Bayes }\end{array}$ & $\begin{array}{l}\text { The decision tree } \\
\text { algorithm gives the } \\
\text { best result in terms of } \\
\text { accuracy, sensitivity, } \\
\text { and specificity in } \\
\text { applying the dataset. } \\
\text { Feature selection } \\
\text { approach is applied } \\
\text { on dataset for CDK } \\
\text { prediction }\end{array}$ & $\begin{array}{l}\text { Dataset 1- } \\
\text { https://archive.ics.uci. } \\
\text { edu/ml/datasets/chronic_ } \\
\text { kidney_disease }\end{array}$ & $\begin{array}{l}\text { Not focused on } \\
\text { elderly }\end{array}$ \\
\hline
\end{tabular}


Table 1. Continued

\begin{tabular}{|c|c|c|c|c|c|c|}
\hline S.No & $\begin{array}{c}\text { Existing } \\
\text { Proposed Model }\end{array}$ & $\begin{array}{c}\text { Identified } \\
\text { diseases }\end{array}$ & Methodology Used & Process Flow & Data collection methods & $\begin{array}{l}\text { Factors still } \\
\text { unexplored }\end{array}$ \\
\hline 8. & $\begin{array}{l}\text { Adeniyi } \\
\text { Onasanya, Maher } \\
\text { Elshakankiri } \\
\text { [Smart integrated } \\
\text { IoT healthcare } \\
\text { system for cancer } \\
\text { care (2019)] } \\
\text { (Onasanya \& } \\
\text { Elshakankiri, } \\
\text { 2019) }\end{array}$ & Cancer disease & $\begin{array}{l}\text { Proposed IoT based } \\
\text { healthcare framework } \\
\text { is discussed for cancer } \\
\text { patients, emphasis on } \\
\text { cancer care services and } \\
\text { business analytics and } \\
\text { cloud services } \\
\text { Based on IoT healthcare } \\
\text { framework and cloud } \\
\text { services }\end{array}$ & $\begin{array}{l}\text { Framework solely for } \\
\text { cancer care patients } \\
\text { with treatment options, } \\
\text { security aspects } \\
\text { covered. } \\
\text { Smart IoT-Enabled } \\
\text { healthcare system is } \\
\text { proposed with sensor } \\
\text { layer, data layer, } \\
\text { hospital layer and } \\
\text { cancer layer. }\end{array}$ & $\begin{array}{l}\text { IoT devices- sensors, } \\
\text { actuators, WSN, IoT } \\
\text { technologies- NFC, BLE, } \\
\text { LPWA, ZigBee. } \\
\text { Real time data collection. }\end{array}$ & $\begin{array}{l}\text { Not focused on } \\
\text { elderly }\end{array}$ \\
\hline 9. & $\begin{array}{l}\text { Johannes Mae, } \\
\text { Endra Oeyand } \\
\text { Ferdian Stanley } \\
\text { Kristiady[ IoT } \\
\text { based body } \\
\text { weight tracking } \\
\text { system for } \\
\text { obese adults } \\
\text { in Indonesia } \\
\text { using real-time } \\
\text { database] 2020 } \\
\text { (Mae et al., } \\
\text { 2020) }\end{array}$ & Obesity & $\begin{array}{l}\text { A system " Digital } \\
\text { weight scale" is } \\
\text { implemented to monitor } \\
\text { weight time to time with } \\
\text { the use of IoT. } \\
\text { Based on IoT and smart } \\
\text { phone application is } \\
\text { modified by digital } \\
\text { weight scale. }\end{array}$ & $\begin{array}{l}\text { The weight scale gives } \\
99 \% \text { accuracy with } \\
\text { real-time data and } 40 \\
\text { hours of usage } \\
\text { Weight scale is used } \\
\text { to measure weight } \\
\text { and data upload to } \\
\text { cloud and access using } \\
\text { application. }\end{array}$ & $\begin{array}{l}\text { A weight scale unit, } \\
\text { smartphone applications, } \\
\text { and real-time database } \\
\text { Real-time database }\end{array}$ & $\begin{array}{l}\text { Not focused on } \\
\text { elderly }\end{array}$ \\
\hline 10. & $\begin{array}{l}\text { Shah, S. T. U., } \\
\text { Badshah, F., } \\
\text { Dad, F., Amin, } \\
\text { N., \& Jan, } \\
\text { M. A. (2019) } \\
\text { [Cloud-Assisted } \\
\text { IoT-Based Smart } \\
\text { Respiratory } \\
\text { Monitoring } \\
\text { System for } \\
\text { Asthma Patients] } \\
\text { (Shah et al., } \\
\text { 2019) }\end{array}$ & Asthma & $\begin{array}{l}\text { proposed a cloud- } \\
\text { assisted IoT-driven } \\
\text { healthcare monitoring } \\
\text { framework for asthma } \\
\text { patients. Based on IoT } \\
\text { services and cloud- } \\
\text { assisted healthcare } \\
\text { system and feature } \\
\text { extraction process }\end{array}$ & $\begin{array}{l}\text { Remote monitoring } \\
\text { of patients health and } \\
\text { data analysis at cloud. }\end{array}$ & $\begin{array}{l}\text { Simulation is done via VM } \\
\text { as java based simulator, a } \\
\text { virtual machine with Intel } \\
\text { Core i3 } 1.7 \mathrm{GHz} \text { processor, } \\
\text { 3GB DDR ECC RAM, } \\
\text { 8MBPS bandwidth, and } \\
\text { running windows server } \\
2012 \text {. } \\
\text { Dataset- https://www. } \\
\text { physionet.org/content/ } \\
\text { bidmc/1.0.0/ }\end{array}$ & $\begin{array}{l}\text { Not focused on } \\
\text { elderly }\end{array}$ \\
\hline
\end{tabular}

EHR triple store, and semantic IoT triple store are coupled in traditional semantic architecture where reasoning and querying are performed in EHR by OWL and some existing ontologies like SSN ontologies, Geo ontologies are used to represent sensor resources and data in IoT triple store. [28] proposed Wearable Healthcare Ontology (WH_Ontology) that aggregates data generated from wearable devices to create valuable knowledge and take the appropriate decision.

Though lots of literature work is exist for integration of semantic technologies and ontology in IoT healthcare systems but very limited studies are available for integration of ontology in IoT healthcare applications for senior citizens. In today's scenario, this is a very prominent challenge that how data should be presented about aged people over the web, so that they can get quick and easy health care services to improve their lifestyle and physical as well as mental health. [29] presents a system named vINCI that provides personalized healthcare services of older adults by exploiting patient's profile using ontologies which ensure good quality of life and automated monitoring for older people but lacking an approach of pre-processing of the initially stored data at an early stage, so that more clear ontologies can be developed. In current worldwide scenario, provision of vaccination is responsible for improved health and prevented 6 million death annually. Impact of vaccines in SARSCoV2 depends on three aspects (1) Health: Eradicate infectious diseases, Immunity; Cancer prevention, vaccine preventable diseases (2) Economic: Cost of Vaccine, Awareness Programme (3) Social: Strengthen healthcare and Empowerment of women.

This article proposed the architecture of an ontology-based IoT healthcare system for senior citizens where pre-processing of data is done at the network edge. 


\section{IOT HEALTHCARE SYSTEM (IHS)}

IoT is one of the emerging technologies that can be considered as a network of interconnected devices to share data with each other without the intervention of any human. It is believed that by 2025 more than 21 billion devices will be connected in the entire world. The healthcare sector is one of the biggest sectors in IoT where devices are directly connected to the human body. IHS offers convenient healthcare services to patients and doctors at their places to diagnose a patient's health and contains the information of patients, doctors, nurses, types of diseases. IHS works on layered architecture, consisting of data perception or data acquisition layer as a base layer where sensors are connected to the human body or nearby humans like smartwatches, smartphones, fitness trackers, smart clothing, and implantable [30].

These miniatures sense and track heartbeat, oxygen saturation level, body temperature, heart rate, pulses, and other activities going on in the body. Data collected at this layer will forward to mobile devices or directly to the cloud from where doctors can access that patient's data and diagnose the health issues (Fig.1(a)). Cloud is a group of data centers, hosts, VMs, resources. Data centers hold various resources and lists of different applications to store the data. Integrating cloud in IoT healthcare opens new ways for rising technologies like Machine Learning, Artificial Intelligence, and data mining to analyze the data and drag valuable results from patient's real-time data so that a quick and better decision can be taken at the right time. Figure 1(a)-(b) depicts a very basic healthcare system where information produced by sensors transmits to server and server then sends all data to the cloud. If processing is required, all data processing is done in the cloud and health care experts can retrieve the patient's data from the cloud and give their feedback directly to patients.

Figure 1a. IoT Healthcare system

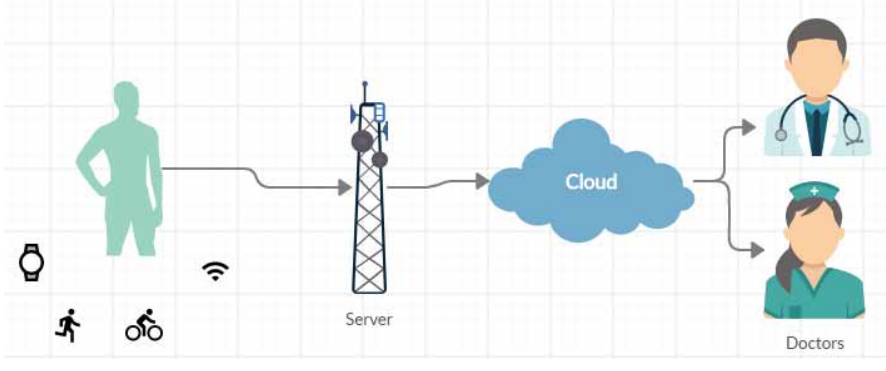

Figure 1b. Class representation in loT healthcare

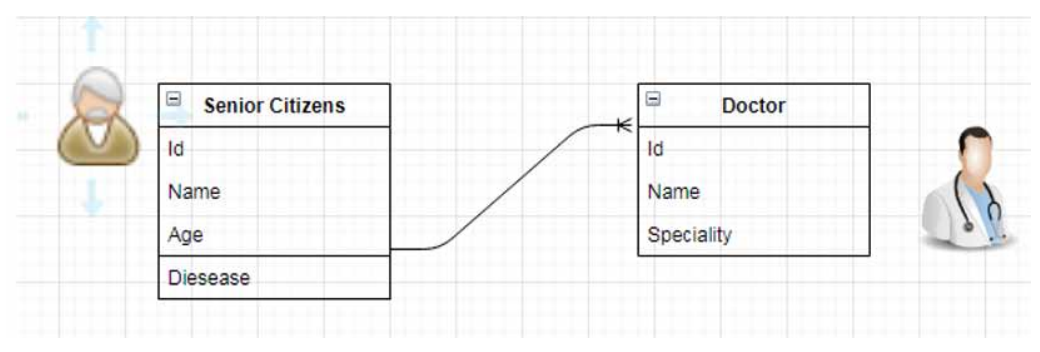




\section{HIGH RISK FACTORS FOR ELDERLY PEOPLE}

Over the past few years, some foremost information communication technologies like- IoT, Big Data, Wireless Sensor Network (WSN), Cloud Computing, and Machine Learning (ML) have spread their roots in the sector of healthcare systems. Data generated by healthcare systems are available in varieties at very rapid speed and vast in nature. And concrete and useful information have to be digging out from this cosmic sea of data. These aforementioned qualities of data satisfy all the V's like- volume, variety, viability, value, velocity, the validity of big data [4] so, healthcare data can be considered as Big data. Due to the gigantic nature of information, handling data in the healthcare system possess some challenges as large scale of data, processing of data, cost, interoperability, integration, security, and privacy [5,6]. Fig.1 presents the risk factor of diseases for infection in Elderly people with age group G1(65-74), G2(75-85), G3(>85). Risk factors for infection in the elderly people as mentioned in fig.1, are raised mainly due to infection in respiratory which causes diseases like bacteria, pneumonia, Influenza, Tuberculosis (chest, spine), and Nosocomial. Other infections like UTI (Urinary Tract Infections), Hepatitis(B-), Clostridioidies difficile, etc. which may deteriorate the health of elderly people and can badly affect organs for the proper functioning of the body. In current COVID 19 scenarios, the risk is very high for patients who are already suffering from cancer, kidney disease, COPD, obesity, diabetes, and cardiomyopathies. However, Coronavirus can badly impact the patients who are suffering from asthma, liver diseases, thalassemia, cystic fibrosis, and hypertension (high blood pressure).

As data Analysis and integration is herculean task so ontology-based services play an important role to collect, integrate, and interpret data to make better decisions. Healthcare data can be present and accessed in ontology via OWL (Web ontology language). Ontology provides a conceptual and categorical view of knowledge that is extracted from healthcare systems [7]. National Center for Health Statistics (NCHS) has categorized older adults in 3 groups as group 1: 66-74 years "Youngold”, group 2: 75-84 years “Old-old”, group 3- 85 above years “The oldest-old”. In today's scenario, the importance of the ontology approach as data produced by healthcare applications is vast and unstructured which needs to be organized in proper format with a smooth flow of data and also results in less request-response time. Ontology $(\mathrm{O})$ presents a formal and explicit representation of terminology and installation. It is defined as:

$\mathrm{O}=\mathrm{TBOX}+\mathrm{ABOX}$

Figure 2. Highly risk factors for Elderly People

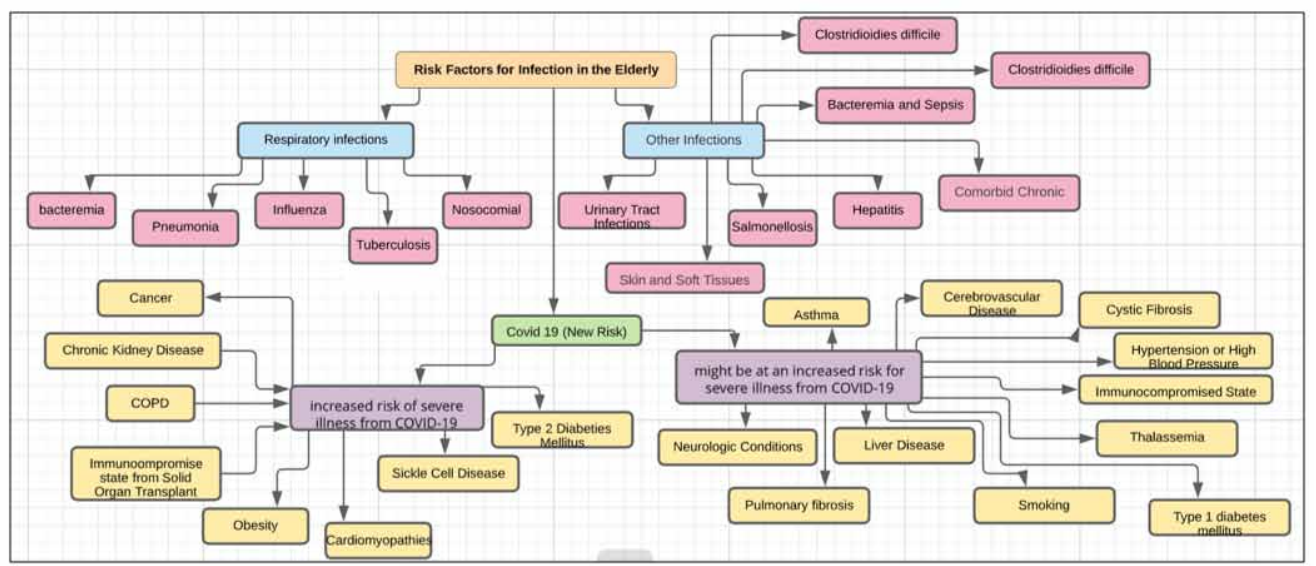


where TBOX represents the Terminological Component, which is a conceptualization associated with a set of facts and ABOX presents the Assertion Component which contains assertions on instances.

In this equation (1), TBOX comprises eight tuples $(C, \leq C, R, \sigma R, \leq R, A, \sigma A, T)$ which represents disjoint sets of C(concepts), $\mathrm{R}$ (Relations), A(Attributes), and $\mathrm{T}$ (Data Types). Further, $\leq \mathrm{C}$ represents concept hierarchy, $\leq \mathrm{R}$ relations hierarchy, $\sigma \mathrm{R}$ represents relations signature which focuses on what concepts are involved in one specific relation of set $\mathrm{R}$ and represents attribute signature which takes the value of certain data type T. ABOX is an ontology installation in the form of Role and Instances.

These older adults face a reduction in their physical ability and having diseases like high blood pressure, blood sugar, asthma, chances to have brain stroke. This is the main challenge to take care of the well-being of older' and to offer them intelligent healthcare systems by which they can monitor their daily routine and get instruction by healthcare providers at the accurate time to make better decisions. The objective and contribution of this article propose ontology for the wellbeing of senior citizens and pre-processing of heterogeneous data at an early stage that is edge network.

\section{FRAMEWORK OF IOT HEALTHCARE SYSTEM}

As demand increases for online healthcare services, it is necessary to develop a system with low cost, more reliability, and security. For this, a firm and smooth framework are required so that data transmission and reception at every layer should take place with ease. Various literature exists with different types of frameworks of HIS. In [31] the author proposed a cloud-IoT based healthcare framework where doctors, patients, and stakeholders can use this framework for their improved results and improved health, respectively. Here, the cloud server provides PaaS and IaaS services to host applications. Authors in [32] proposed a framework for real-time data with a multilayer framework with the incorporation of layer between the sensing layer and cloud so that basic pre-processing can be done at this new layer. [33] presents an IoT based computational framework to monitor the health of patients in mobile environments also and validate this proposed framework with a case study of footballers' heart rate data. Another framework is also proposed for ECG monitoring system where ECG data is collected than signal enhancing and watermarking for security is done during data collection and some machine learning process like features extraction and classification is done at cloud [34]. In figure 4, a basic framework is presented where the base layer is an IHS sensor layer

Figure 3. Ontology Representation

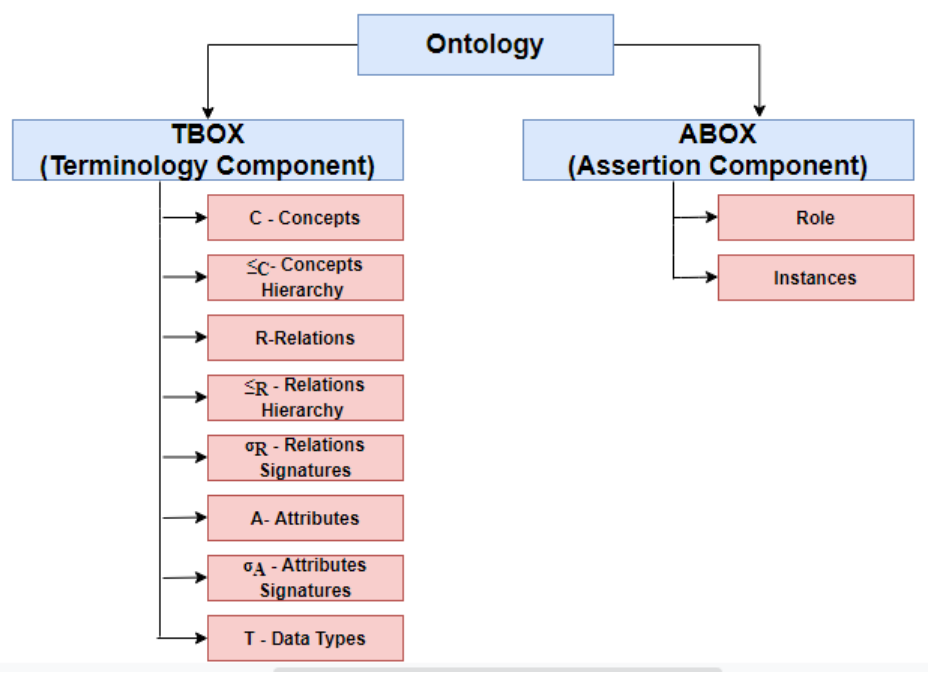




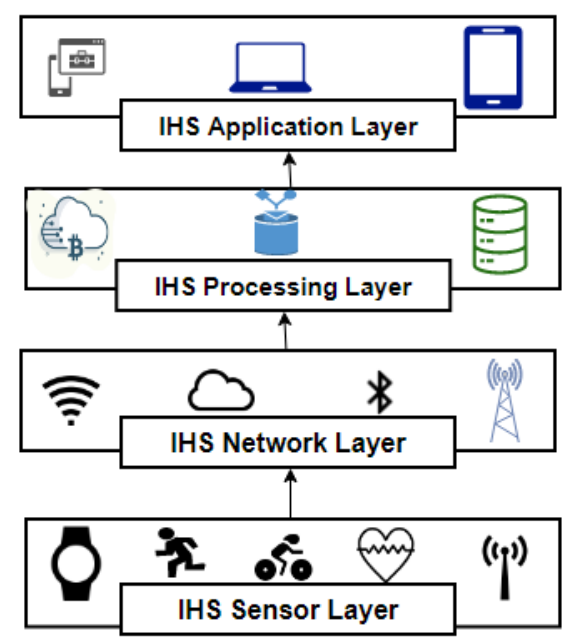

where deployed sensors create networks among them to sense the body area and acquire data from RFID tags, fit bands, heart rate sensors, and many more.

IHS framework encompasses four layers where the first layer is a sensor layer that incorporated all IoT gadgets like sensors, wearables, smartwatches, actuators, RFID tags. These gadgets are deployed around the physical environment of patients to monitor physiological and vital parameters and data collected through these sensors are sent to the network layer via various IoT technologies like ZigBee, Bluetooth, LPWAN, WI-FI, 6LowPAN. The network layer comprises gateways and edge routers that play the role of a bridge between the sensor layer and the data processing layer. The data processing layer is responsible for applying analytics to raw data gathered by the sensor layer where analytics can be done locally or globally. Local data analysis can be performed at edge router nearer to the devices to divide the burden of the network. Global data analysis can be done in the cloud by applying some data mining and machine learning algorithms to detect the pattern and predict the next values. This analyzed data or useful knowledge will pass to the application layer via the IoT application layer protocol like MQTT, COAP. These protocols present data to users in terms of any desktop applications or any mobile applications. patients can get a view about their signs and get instructions from doctors and nurses.

\section{Methodology Used for Strengthening Healthcare System}

Due to the rapid proliferation of diseases, numerous encoding concepts and ontologies related terms are used in the medical domain. Ontologies like SNOMED (Systematized Nomenclature of Medicine), ICD (International Classification of diseases) offer systematic, computer processable collection of medical terms in humans as well as veterinary medicines to provide encoding terminologies. Further, SNOMED-CT extends support internationally and provides access to terminology and health data related resources in COVID 19 as well [35]. Patients already suffering from diseases Pneumonia, diabetes, asthma, hypertension, cardiovascular, Obesity, chronic kidney have high risk factor of infection from Covid 19 (Table 2).

Figure 5 portrays the flow of data, from the generation of data to become smart data for elderly people IoT healthcare applications. This process involves various sub processes that are as follows: 
Table 2. Referred Algorithm used for diseases

\begin{tabular}{|l|l|l|}
\hline \multicolumn{1}{|c|}{ S. No. } & \multicolumn{1}{c|}{ Diseases } & \multicolumn{1}{c|}{ Algorithm Used } \\
\hline 1. & Glaucoma Diagnosis & Logical Regression [36] \\
\hline 2. & Alzheimer's Disease & Linear Regression [37] \\
\hline 3. & Diagnose Bacterial Sepsis & Random Forest(RF) and ANN[38] \\
\hline & & $\begin{array}{l}\text { Naïve Bayes Algorithm [ 39] } \\
\text { Logistic Regression Algorithm [39] } \\
\text { Artificial Neural Network [40] } \\
\text { K- Nearest Neighbor [41] }\end{array}$ \\
\hline
\end{tabular}

Figure 5. Ontology-based loT healthcare system for senior citizens

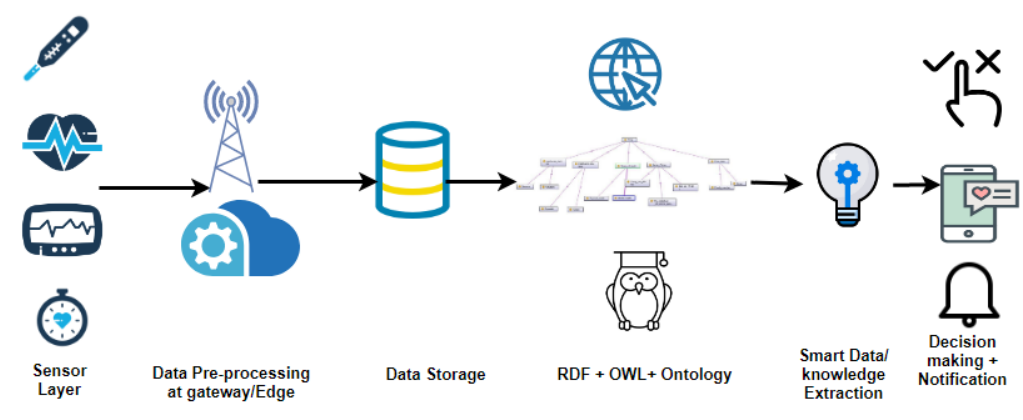

1. Sensor Layer: Various sensors are attached to the older adult's body to sense the parameters of their body. These sensors include an oximeter, electrocardiogram, thermometer, fluid level sensor, blood pressure sensor to read the current situation of patients. These sensors have low battery and low memory so used only to sense and transfer the data to the upper layer. No processing is done at this stage. In live tracking of records of individual patient is not satisfactory; then superintending of patient process is executed virtually. For tracing and clustering Data Processing module is initiated.

2. Data Preprocessing at Edge: Data generated by sensors are sent to gateways at the network layer through various technologies like Bluetooth, Wi-Fi, ZigBee, LoRaWAN,5G, LTE. Gateway will store that data packets and sometimes these gateways are available near devices called edges of the network. Basic data processing can be done locally at edge routers. Pre-processing of data involves cleaning, eliminating duplicate packets, normalization of data, basic data aggregation (SUM, AVG, MAX, MIN), and pre-processed data transmitted to the cloud; result in no more burden there. Portable devices like smartphones, smartwatches, compact embedded systems, and compact gateways perform the aforementioned pre-processing tasks.

3. Data Storage: This stage can be considered as a warehouse or cloud. Data stored at this stage is huge. Machine Learning, deep learning, and data mining algorithms are applied here to analyze as well as extract knowledge from data.

4. RDF/OWL/Ontology Layer: Data stored in the storage is used by the semantic web. Semantic web sanctifies knowledge from data in such a way that improves decision making. Semantic web technologies include RDF and OWL. RDF linked the opened data over the web and present data in triple format "subject-predicate-object" which provides structure and unique identifiers. Ontology presents a knowledge model that identifies a set of concepts also called classes and 
tries to define relationships among concepts in a particular domain. The knowledge presented by ontology can be shared and reused at any time. Figure 4 shows the proposed ontology for senior citizens IoT healthcare systems developed by protégé software. Here five classes are identified name- senior citizens, healthcare providers, caretakers, healthcare devices, and types of health. The senior citizen class is further categorized into 3 subclasses as "Young old", "Old-old", and "The oldest old". Similarly, the type of health class is divided into physical health and sub heath and other classes are also having subclasses. Properties are defined for different users like senior citizens along with properties name, Id, age whereas doctor has characteristics like id, name, area of specialization. Relationships among classes show links between pairs of classes. For example:

a. Physician is-a-subclass-of healthcare provider (superclass to subclass relation);

b. Senior citizens has-a mental health or physical health (class to class relation);

c. Senior citizen uses healthcare devices (class to class relation).

5. Smart Data: RDF and OWL are used together to provide smart data, data that can be read and understandable by machine without any human intervention, and able to apply reasoning. When every device and file used in an IoT healthcare system is represented by ontology and linked together over the web then the machine can co-relate and visualize the flow of data, this results in better performance of the system. This data is used for ambulance service; if patent requires hospitalization then ambulance service will be provided and patient information will also be shared with hospital.

6. Decision Making: Ontological Meta-data helps healthcare users and healthcare providers to take all necessary steps towards their quality of life and it helps the decision support system (DSS) to decide where to send a notification to patients or caretakers based on ontology-driven advice.

\section{Research Findings and Comparative Analysis of Worldwide Disease Infections Effect on Elderly Senior Citizens}

The coronavirus disease was declared a pandemic by WHO (World Health Organization) on March 13th. The attempt [42] discussed about virus infection and its impact in current scenario as well as recent development. Everyday constantly COVID Cases are rapidly increasing worldwide as time passes while healthcare providers and government bodies are putting efforts to stop the spread of this virus. Europe [43] is one of the most affected continents in which countries like Italy, Spain, the UK, and France. In [44] authors mentioned that the tropical regions are relatively less prone to COVID-19 cases than the European \& American regions and transmission of spread is not uniform globally. They also conclude that the death rate is mostly subjective to age group and medical history. Table 3 presents a reasonable analysis of new COVID-19 cases reported in the last 24 hours concerning deaths reported in the last 24 hours on 9th September 2020(WHO). The table 3 presents data from four foremost countries in Covid-19 cases.

Table 3. Comparative Analysis of Cumulative Cases Vs Deaths reported in 24 hours on September 9th, 2020

\begin{tabular}{|l|l|l|l|l|l|}
\hline \multicolumn{1}{|c|}{ Country Name } & \multicolumn{1}{|c|}{$\begin{array}{c}\text { Cases } \\
\text { Cumulative } \\
\text { total }\end{array}$} & $\begin{array}{c}\text { Cases newly } \\
\text { reported in the } \\
\text { last 24 years }\end{array}$ & $\begin{array}{c}\text { Death Total } \\
\text { Cumulative }\end{array}$ & $\begin{array}{c}\text { Deaths newly } \\
\text { reported in the } \\
\text { last 24 hours }\end{array}$ & \multicolumn{1}{|c|}{$\begin{array}{c}\text { Transmission } \\
\text { Classification }\end{array}$} \\
\hline India & $4,280,422$ & 75,809 & 72,775 & 1,133 & Cluster of Cases \\
\hline US & $6,222,974$ & 33,486 & 188,003 & 462 & $\begin{array}{l}\text { Community } \\
\text { Transmission }\end{array}$ \\
\hline Brazil & $4,137,521$ & 14,521 & 126,650 & 447 & $\begin{array}{l}\text { Community } \\
\text { Transmission }\end{array}$ \\
\hline Russia & $1,035,789$ & 5,099 & 17,993 & 122 & Cluster of Cases \\
\hline
\end{tabular}


The figure 6 presents that the U.S has the highest cumulative cases and India has become the first country in the world with reporting the highest cases and deaths in the last 24 hours. According to the world population prospects, current population of India stood at $1,352,642,280$. By 2030, it is expected its population by 1.5 billion people. $35 \%$ percent of its population below the age of 25 and more than $65 \%$ age below the age of 35 . Table 4 presents high level of infections spread among old age people across the globe during Covid 19.

Figure 7(a-c) depicts the worldwide count of COVID 19 cases raised frequently shown in the figure that the Brazil, China, India, USA has the highest cases surpassed confirmed cases for elderly people.

The dataset results mentioned in Fig 9 presents positive cases confirmed per age group. Age groups are binned into the eight groups $<\mathrm{G} 1$ : under 18, G2: 18-30, G3:31-40, G4:41-50, G5:51-60, G6:61-70, G7: 71-80 and G8: 81+>. Information of cases are classified based on cluster case and community transmission. As per HT reports, most of deaths due to Covid 19 across nation were in age group between 50-70 out of which highest age group was in between 61-70 age among both genders. However, male death ratio is almost $69 \%$ and higher as compared to females.

To prevent world from COVID-19 pandemic, doctors, researchers, and government officials are in much action and succeed Within less than 12 months after the beginning of the COVID-19 in developing and authorize vaccine. Vaccines are always helps to save life of million people each year. Vaccine makes human body's immune system strong and prevents from illness. As this pandemic is very fearful and people are dying, so it is immense requirement to develop vaccine against this virus.

After so much of hard work doctors are succeed in developing vaccines and as of 18 February 2021, at least 7 different vaccines have been approved and rolled out in countries where as more than 200 vaccines are in under development [WHO]. There are companies which provide vaccines are Pfizer, Serum Institute of India, Moderna, BioNtech, Fosun Pharma and many more [45]. Vaccination has been started in December 2020 in countries like UK, Russia, China, Israel[Fig.9]. In a study it is find that, one third (33 percent) of people in group who have already coronavirus reported "mild

Figure 6. Situation of COVID 19 Effect in Top 4 most affected Countries (As per report 9th September 2020)

\section{Situation of Covid 19 Effect Current Scenario}

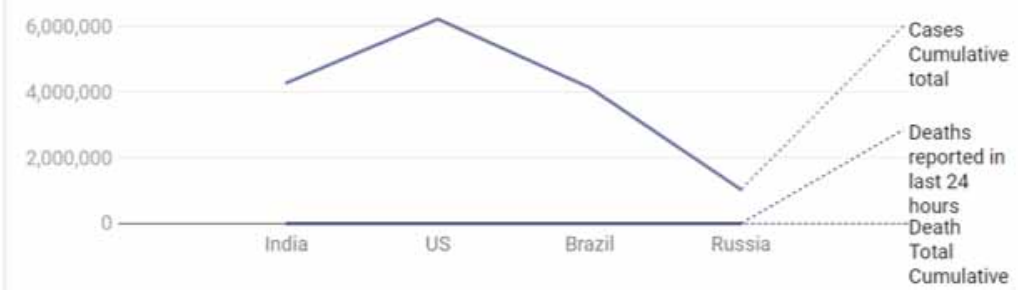

Table 4. High risk infection rate during Covid Scenario in elderly people

\begin{tabular}{|l|l|l|l|l|}
\hline \multicolumn{1}{|c|}{ Disease Name } & \multicolumn{1}{c|}{ Age Group } & \multicolumn{1}{c|}{ Covid 19 } & \multicolumn{1}{c|}{ Affected tract } & \multicolumn{1}{c|}{ Organ specific } \\
\hline Bacterial pneumonia & $60-65$ & SARS Cov-2 & Respiratory tract & Lung \\
\hline Elderly influenza & $80+$ & SARS Cov-2, H1N1 & $\begin{array}{l}\text { Lower and upper both } \\
\text { Respiratory tract }\end{array}$ & $\begin{array}{l}\text { Heart, Brain and } \\
\text { muscles }\end{array}$ \\
\hline $\begin{array}{l}\text { Elderly skin } \\
\text { infections }\end{array}$ & $65+$ & HSV type1 & $\begin{array}{l}\text { Methicillin-resistant } \\
\text { Staphylococcus aureus }\end{array}$ & Internal organs \\
\hline $\begin{array}{l}\text { Gastrointestinal } \\
\text { infections }\end{array}$ & $80+$ & $\begin{array}{l}\text { Rotavirus, Adenovirus, } \\
\text { Astrovirus, Calicivirus }\end{array}$ & Gastrointestinal tract & $\begin{array}{l}\text { Stomach and Small } \\
\text { Intestine }\end{array}$ \\
\hline
\end{tabular}


Figure 7a. Mapping of Cases raised frequently country wise Elderly people age (75-84) (Source: https://covid19.who.int/ table?tableChartType=heat)

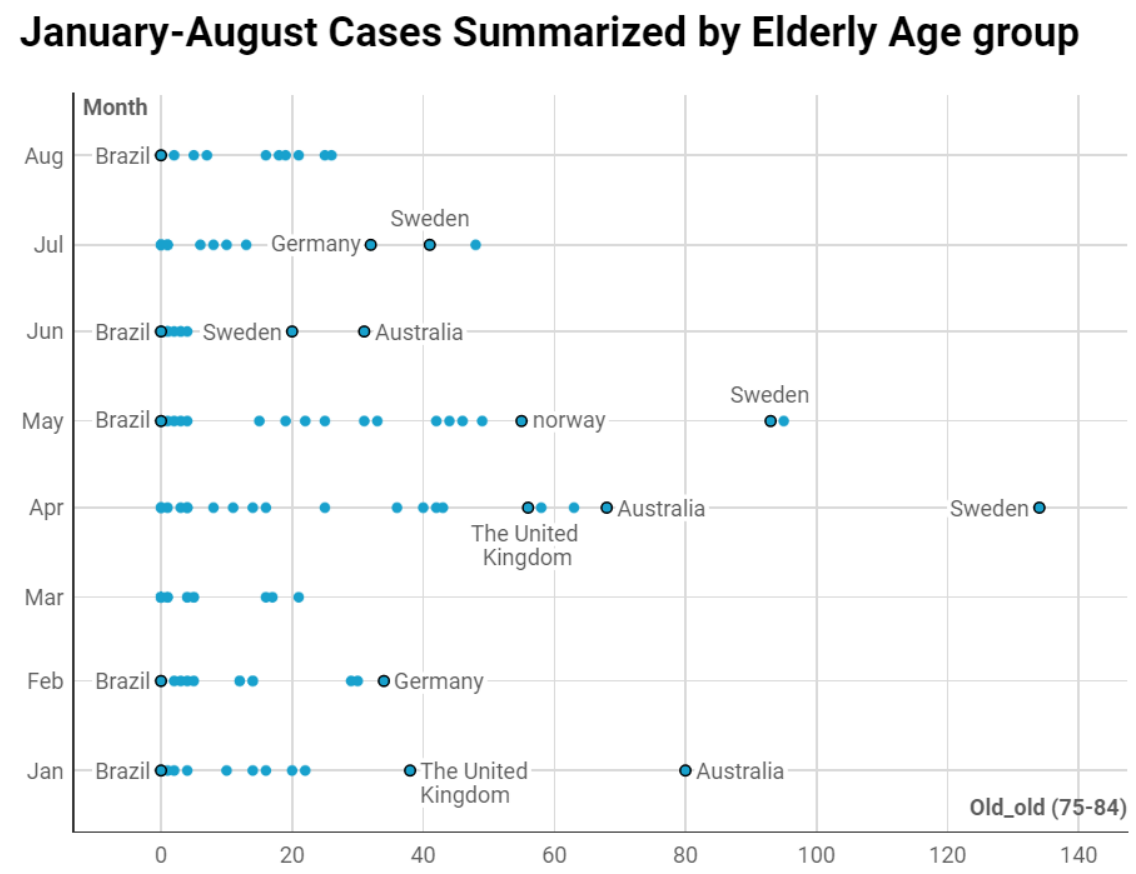

Figure 7b. Mapping of Cases raised frequently country wise Elderly people age (65-74) (Source: https://covid19.who.int/ table?tableChartType=heat)

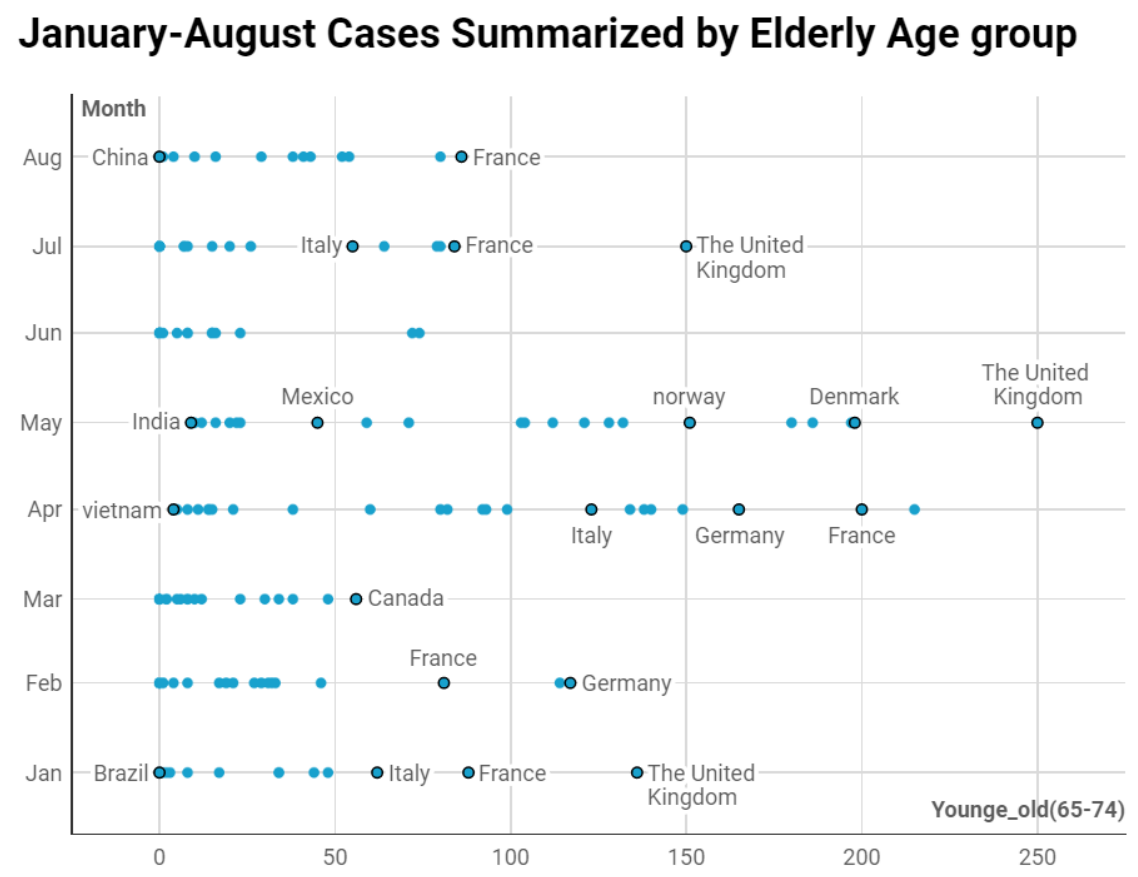


Figure 7c. Mapping of Cases raised frequently country wise Elderly people age (85 Above) (Source: https://covid19.who.int/ table?tableChartType=heat)

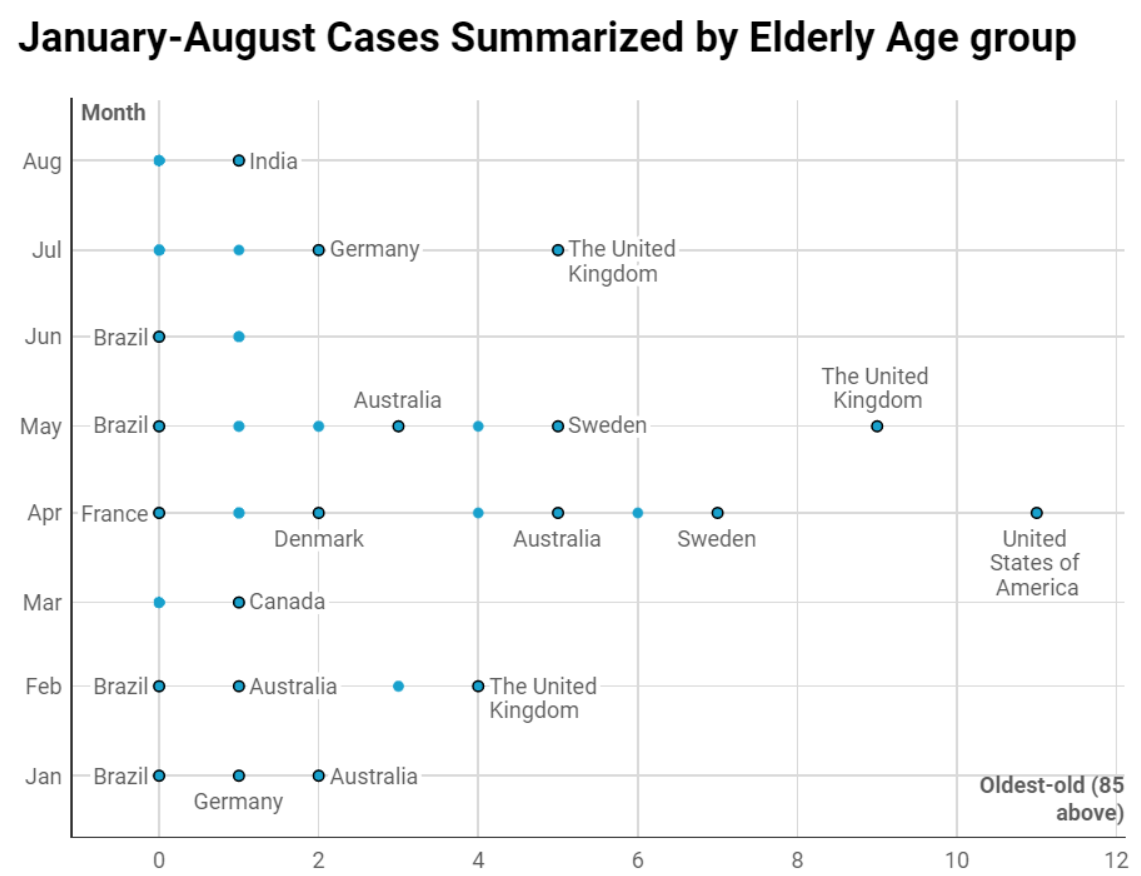

Figure 8. Impact of Covid19 on different age group as per timeliness (Source: https://dataverse.harvard.edu/dataset. xhtml?persistentld=doi:10.7910/DVN/8UTBVA)

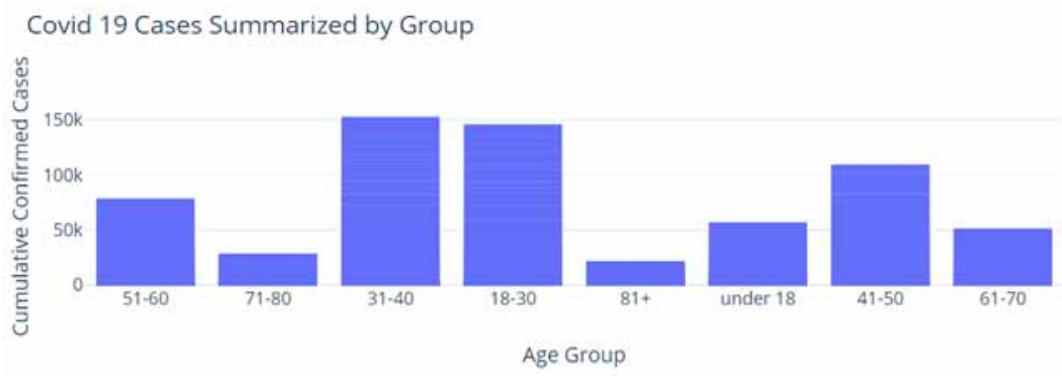

whole-body" side effects such as fatigue, headache and shivers after their first dose, compared with one fifth (19 percent) of patients who had not had COVID [46].

\section{CONCLUSION}

In this paper, IoT based health care system is presented to alleviate the problems by chronic diseases.

The presented ontology-based healthcare architecture will be benefitted older people as they are facing challenges of loneliness, depression, physical disability, and weak immunity. They can improve their quality of life and monitor regularly their health beyond the doctor's office. Healthcare providers 
Figure 9. Specific vaccination dose regime [January-February 20,2021]

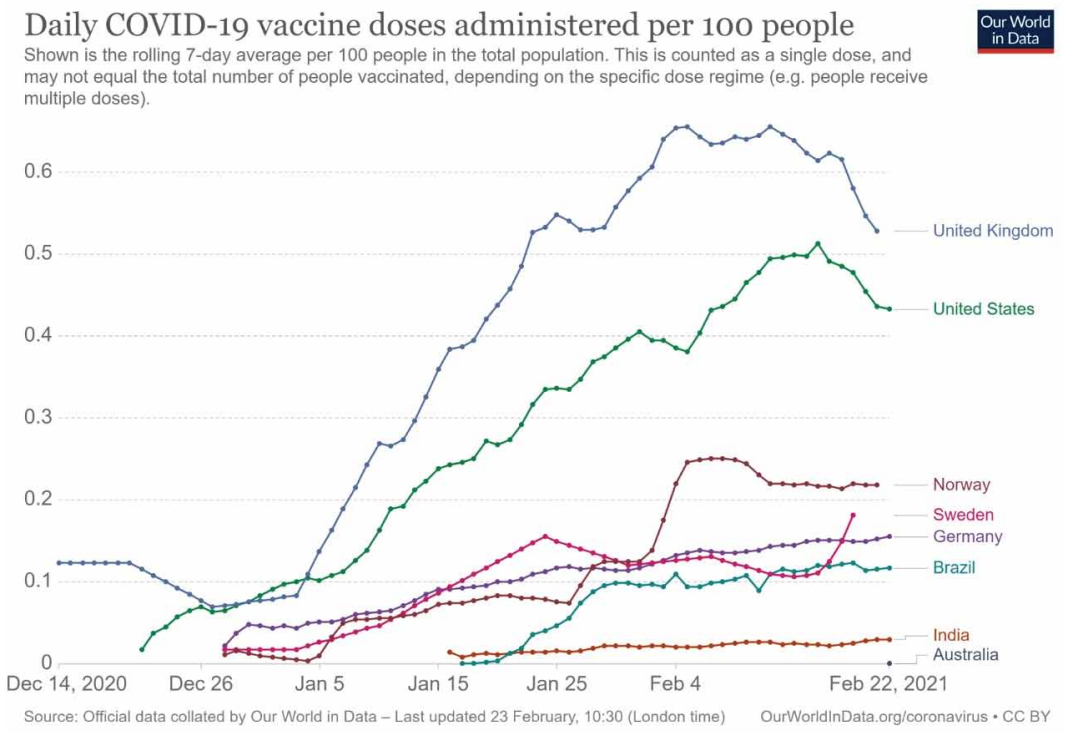

will get real-time data of a patient's health status and advise them accordingly and send notification and alerts. To fetch smart data in less time from web, ontology-based healthcare systems are most preferred. In the future, this work will be enhanced by incorporating an IoT based care plan features for monitoring a person's health conditions as well as medications too. Elderly people will continuously receive information from healthcare providers for overcoming their physical and hypertension issues through yoga, exercises, and meditation guidelines. Excessive intake of medicines may generate issues of multi-organ failure in old age people, so guidelines to physical exercise will be a source of motivation for them. This system will also keep track of emergency contacts and information serious patients on a timely basis. In the case of inconsequence, information of patients would be updated by health care providers to nearby healthcare so that treatment can be done without delay. This concept will be helpful for elderly patients who are living alone but will receive appropriate care in an emergency situation. 


\section{REFERENCES}

W3. (n.d.). Sematic Web. https://www.w3.org/standards/semanticweb/

Abinayaa, B., \& Raja, A. (2016). Smart portable monitoring device for asthma patients. Middle East Journal of Scientific Research, 24(S1), 136-142.

Al-Khafajiy, M., Baker, T., Chalmers, C., Asim, M., Kolivand, H., Fahim, M., \& Waraich, A. (2019). Remote health monitoring of elderly through wearable sensors. Multimedia Tools and Applications, 78(17), 24681-24706. doi:10.1007/s11042-018-7134-7

Alamri, A. (2018). Ontology middleware for integration of IoT healthcare information systems in EHR systems. Computers, 7(4), 51. doi:10.3390/computers7040051

Bajenaru, L., Dobre, C., Ciobanu, R. I., \& Balog, A. (2019, November). Patient Profile Using Ontologies in an Older Adults Monitoring IoT-Based Platform. In 2019 E-Health and Bioengineering Conference (EHB) (pp. 1-4). IEEE. doi:10.1109/EHB47216.2019.8970027

Basanta, H., Huang, Y. P., \& Lee, T. T. (2016, April). Intuitive IoT-based H2U healthcare system for elderly people. In 2016 IEEE 13th International Conference on Networking, Sensing, and Control (ICNSC) (pp. 1-6). IEEE. doi:10.1109/ICNSC.2016.7479018

Bhagwat, N., Viviano, J. D., Voineskos, A. N., \& Chakravarty, M. M. (2018). Modeling and prediction of clinical symptom trajectories in Alzheimer's disease using longitudinal data. PLoS Computational Biology, 14(9), e1006376. doi:10.1371/journal.pcbi.1006376 PMID:30216352

Bioportal. (n.d.). COVID-19. https://bioportal.bioontology.org/ontologies/COVID-19

COVID. (n.d.). https://covid.joinzoe.com/post/vaccine-after-effects-more-common-in-those-who-already-hadcovid

Cruz, I. F., \& Xiao, H. (2005). The role of ontologies in data integration. Engineering Intelligent Systems for Electrical Engineering and Communications, 13(4), 245.

Darwish, A., \& Hassanien, A. E. (2011). Wearable and implantable wireless sensor network solutions for healthcare monitoring. Sensors (Basel), 11(6), 5561-5595. doi:10.3390/s110605561 PMID:22163914

Elaziz, M. A., Hosny, K. M., Salah, A., Darwish, M. M., Lu, S., \& Sahlol, A. T. (2020). New machine learning method for image-based diagnosis of COVID-19. PLoS One, 15(6), e0235187. doi:10.1371/journal.pone.0235187 PMID:32589673

Hassen, H. B., Dghais, W., \& Hamdi, B. (2019). An E-health system for monitoring elderly health based on Internet of Things and Fog computing. Health Information Science and Systems, 7(1), 24. doi:10.1007/s13755019-0087-z PMID:31695910

Hossain, M. S., \& Muhammad, G. (2016). Cloud-assisted industrial internet of things (iiot)-enabled framework for health monitoring. Computer Networks, 101, 192-20. doi:10.1016/j.comnet.2016.01.009

Hosseinzadeh, M., Koohpayehzadeh, J., Bali, A. O., Asghari, P., Souri, A., Mazaherinezhad, A., \& Rawassizadeh, R. et al. (2020). A diagnostic prediction model for chronic kidney disease in internet of things platform. Multimedia Tools and Applications, 1-18. doi:10.1007/s11042-020-09049-4

Islam, S. R., Kwak, D., Kabir, M. H., Hossain, M., \& Kwak, K. S. (2015). The internet of things for health care: A comprehensive survey. IEEE Access: Practical Innovations, Open Solutions, 3, 678-708. doi:10.1109/ ACCESS.2015.2437951

Jangra, P., \& Gupta, M. (2018, August). A design of real-time multilayered smart healthcare monitoring framework using IoT. In 2018 International Conference on Intelligent and Advanced System (ICIAS) (pp. 1-5). IEEE. doi:10.1109/ICIAS.2018.8540606

Jara, A. J., Zamora, M. A., \& Skarmeta, A. F. (2011). An internet of things-based personal device for diabetes therapy management in ambient assisted living (AAL). Personal and Ubiquitous Computing, 15(4), 431-440. doi:10.1007/s00779-010-0353-1 
Khalil, T., Khalid, S., \& Syed, A. M. (2014, August). Review of Machine Learning techniques for glaucoma detection and prediction. In 2014 Science and Information Conference (pp. 438-442). IEEE. doi:10.1109/ SAI.2014.6918224

Kouris, I., \& Koutsouris, D. (2014). Identifying risky environments for COPD patients using smartphones and internet of things objects. International Journal of Computational Intelligence Studies, 3(1), 1-17. doi:10.1504/ IJCISTUDIES.2014.058642

Kumar, V. (2015). Ontology based public healthcare system in Internet of Things (IoT). Procedia Computer Science, 50, 99-102. doi:10.1016/j.procs.2015.04.067

Lal, P., Kumar, A., Kumar, S., Kumari, S., Saikia, P., Dayanandan, A., Adhikari, D., \& Khan, M. L. (2020). The dark cloud with a silver lining: Assessing the impact of the SARS COVID-19 pandemic on the global environment. The Science of the Total Environment, 732, 139297. doi:10.1016/j.scitotenv.2020.139297 PMID:32408041

Lee, H., Park, Y. R., Kim, H. R., Kang, N. Y., Oh, G., Jang, I. Y., \& Lee, E. (2020). Discrepancies in Demand of Internet of Things Services Among Older People and People With Disabilities, Their Caregivers, and Health Care Providers: Face-to-Face Survey Study. Journal of Medical Internet Research, 22(4), e16614. doi:10.2196/16614 PMID:32293575

Li, C., Hu, X., \& Zhang, L. (2017). The IoT-based heart disease monitoring system for pervasive healthcare service. Procedia Computer Science, 112, 2328-2334. doi:10.1016/j.procs.2017.08.265

Ma, X., Wang, Z., Zhou, S., Wen, H., \& Zhang, Y. (2018, June). Intelligent healthcare systems assisted by data analytics and mobile computing. In 2018 14th International Wireless Communications \& Mobile Computing Conference (IWCMC) (pp. 1317-1322). IEEE. doi:10.1109/IWCMC.2018.8450377

Mae, J., Oey, E., \& Kristiady, F. S. (2020). IoT based body weight tracking system for obese adults in Indonesia using realtime database. $E \& E S, 426(1), 012143$. doi:10.1088/1755-1315/426/1/012143

Maglogiannis, I. (2009). Introducing intelligence in electronic healthcare systems: state of the art and future trends. In Artificial Intelligence An International Perspective (pp. 71-90). Springer. doi:10.1007/978-3-642-03226-4_5

Mezghani, E., Exposito, E., Drira, K., Da Silveira, M., \& Pruski, C. (2015). A semantic big data platform for integrating heterogeneous wearable data in healthcare. Journal of Medical Systems, 39(12), 185. doi:10.1007/ s10916-015-0344-x PMID:26490143

Mora, H., Gil, D., Terol, R. M., Azorín, J., \& Szymanski, J. (2017). An IoT-based computational framework for healthcare monitoring in mobile environments. Sensors (Basel), 17(10), 2302. doi:10.3390/s17102302 PMID:28994743

Muhammad, L. J., Algehyne, E. A., Usman, S. S., Ahmad, A., Chakraborty, C., \& Mohammed, I. A. (2021). Supervised Machine Learning Models for Prediction of COVID-19 Infection using Epidemiology Dataset. SN Computer Science, 2(1), 1-13.

Narin, A., Kaya, C., \& Pamuk, Z. (2020). Automatic detection of coronavirus disease (covid-19) using x-ray images and deep convolutional neural networks. arXiv preprint arXiv:2003.10849

Onasanya, A., \& Elshakankiri, M. (2019). Smart integrated IoT healthcare system for cancer care. Wireless Networks, 1-16. doi:10.1007/s11276-018-01932-1

Park, S. J., Subramaniyam, M., Kim, S. E., Hong, S., Lee, J. H., Jo, C. M., \& Seo, Y. (2017). Development of the elderly healthcare monitoring system with IoT. In Advances in Human Factors and Ergonomics in Healthcare (pp. 309-315). Springer. doi:10.1007/978-3-319-41652-6_29

Pillai, S., Siddika, N., Apu, E. H., \& Kabir, R. (2020). COVID-19: Situation of European Countries so Far. Archives of Medical Research.

Pinto, S., Cabral, J., \& Gomes, T. (2017, March). We-care: An IoT-based health care system for elderly people. In 2017 IEEE International Conference on Industrial Technology (ICIT) (pp. 1378-1383). IEEE. doi:10.1109/ ICIT.2017.7915565

Pramanik, P. K. D., Pal, S., \& Mukhopadhyay, M. (2019). Healthcare big data: A comprehensive overview. In Intelligent Systems for Healthcare Management and Delivery (pp. 72-100). IGI Global. 
Ray, P. P. (2014, November). Home Health Hub Internet of Things (H 3 IoT): An architectural framework for monitoring health of elderly people. In 2014 International Conference on Science Engineering and Management Research (ICSEMR) (pp. 1-3). IEEE. doi:10.1109/ICSEMR.2014.7043542

Recalcati, S. (2020). Cutaneous manifestations in COVID-19: a first perspective. Journal of the European Academy of Dermatology and Venereology.

Rodriguez-Morales, A. J., Bonilla-Aldana, D. K., Tiwari, R., Sah, R., Rabaan, A. A., \& Dhama, K. (2020). COVID-19, an emerging coronavirus infection: Current scenario and recent developments-an overview. Journal of Pure \& Applied Microbiology, 14(1), 6150. doi:10.22207/JPAM.14.1.02

Shah, S. T. U., Badshah, F., Dad, F., Amin, N., \& Jan, M. A. (2019). Cloud-assisted IoT-based smart respiratory monitoring system for asthma patients. In Applications of Intelligent Technologies in Healthcare (pp. 77-86). Springer. doi:10.1007/978-3-319-96139-2_8

Szilagyi, I., \& Wira, P. (2016, October). Ontologies and Semantic Web for the Internet of Things-a survey. In IECON 2016-42nd Annual Conference of the IEEE Industrial Electronics Society (pp. 6949-6954). IEEE. doi:10.1109/IECON.2016.7793744

Tun, S. Y. Y., Madanian, S., \& Mirza, F. (2020). Internet of things (IoT) applications for elderly care: A reflective review. Aging Clinical and Experimental Research, 1-13. doi:10.1007/s40520-020-01545-9 PMID:32277435

Tyagi, S., Agarwal, A., \& Maheshwari, P. (2016, January). A conceptual framework for IoT-based healthcare system using cloud computing. In 2016 6th International Conference-Cloud System and Big Data Engineering (Confluence) (pp. 503-507). IEEE. doi:10.1109/CONFLUENCE.2016.7508172

Wang, X., Wang, Z., Weng, J., Wen, C., Chen, H., \& Wang, X. (2018). A new effective machine learning framework for sepsis diagnosis. IEEE Access: Practical Innovations, Open Solutions, 6, 48300-48310. doi:10.1109/ACCESS.2018.2867728

WHO. (2021). Status. https://extranet.who.int/pqweb/sites/default/files/documents/Status_COVID_ VAX_16Feb2021.pdf

Yadav, P., Steinbach, M., Kumar, V., \& Simon, G. (2018). Mining Electronic Health Records (EHRs) A Survey. ACM Computing Surveys, 50(6), 1-40. doi:10.1145/3127881

Sakshi Gupta has received her Bachelor of Computer Applications and Master of Computer Applications from Uttar Pradesh Technical University (Now Dr APJ AKTU), Lucknow, Uttar Pradesh. She was amongst TOP2 Meritorious student of MCA and had won Scholarship. Currently. She is doing Ph.D. from Birla Institute of technology Mesra, Ranchi. She has experience of more than 3 years in Academics. She has keen interest in the area of Internet of Things, Mobile Ad hoc network, and Wireless Sensor networks. She has published about 5 research Papers in reputed Conferences at national/international level indexed in including ESCl, Scopus, Google Scholar. She has also attended various technical Conferences/Workshops/Faculty Development Programmes/Orientation Programmes from organization repute.

Umang Singh $(P h D)$ is presently working as Associate Professor in Institute of Technology \& Science, Ghaziabad. She is renowned for her keen interest in the area of Mobile Networks, IoT, Data Analytics and Machine learning. Dr. Umang has experience of more than 17 Years in Academics. She is involved in active research and has been guiding M.Tech, Ph.D. students. She has published about 80+ research Papers in reputed Journals \& Conferences indexed in including SCI,ESCI, SCIE, Scopus, Google Scholar, Thomas Reuters, DBLP credited to her name. She served as Guest Editor for special issues of journals which include "International Journal of e-Collaborations"(IGI Global, USA, 2020), American Journal of Artificial Intelligence(SciencePG, NY,USA, 2020) and International Journal of Information Technology (BJIT 2010) Special Issue and edited 6 Proceedings, 3 Souvenir and 4 Books. Dr Umang is Board of Referees Springer IJIT(Scopus Indexed), Editorial Board Member Inderscience IJFSE(Switzerland) and Technical Programme Committee of national/international journals/Conferences/Seminars repute. Dr. Umang has also delivered session as Keynote Speaker/chaired/conducted a Technical Sessions in Conferences/Workshops/Faculty Development Programmes/ Orientation Programmes repute. Dr Umang is Senior Member of IEEE, Member of Computer Society of India, IAENG, MIR Labs etc. Dr. Umang has been delivering invited talks, guest talks at prominent places and organizations including Indian Air Force. Dr. Umang has received Certificate of Appreciation from VSM, Airforce Station Hindan, Ghaziabad (UP). Dr. Umang has received "Young Active Member award" for year 2007-2008 from Computer Society of India. She has also received "Young Faculty in Science" in Year 2017 from VIFA, Chennai. 